\title{
The Mediating effect of Corporate Social Responsibility and Dividend Policy on the Effect of Corporate Governance Mechanism on Firm Value among Publicly Listed Companies in the Philippines
}

\author{
Mia B. Bermundo, Rodiel C. Ferrer, Franklin Ramirez
}

\begin{abstract}
Corporate social obligation has become an vital part of commercial company exercise during the last decade or so. In fact, many businesses dedicate a phase of their annual reports and company internet web sites to CSR activities, illustrating the importance they attach to such sports. On the opposite hand, Good company governance exercise has a number of observable outcomes on economic results of the company. Corporate governance recommendations are strongly associated with income quality or the quantity to which the firm's disclosed economic basic performance reflects its right performance. This have a look at investigates in the main the mediating effect of Corporate Social Responsibility and Dividend Policy on the impact of corporate governance mechanism on firm value amongst publicly listed organizations inside the Philippines. It examined forty seven publicly indexed businesses inside the Philippines for a four-yr period from 2013 to 2016. A structural equation modeling (SEM) approach changed into used for the evaluation. Results show that Corporate Social Responsibility does not act as a mediating variable with regards to company governance mechanisms to firm rate. It manner that CSR does now not act as a variable so one can give a boost to corporation governance mechanisms that during developing the charge of the commercial enterprise corporation. Also, dividend coverage does no longer act as mediating variable at the effect of enterprise governance mechanisms on company value. Finally, the end result confirmed that there is a terrible but large effect of dividend price on business enterprise value.
\end{abstract}

Index Terms-: Corporate Social Responsibility, Dividend Policy, Corporate Governance, Firm Value

\section{INTRODUCTION}

A corporation no longer exceptional operates for the advantage of shareholders, but additionally for the pastimes of the stakeholders in corporation practices via the implementation of corporate social responsibility (CSR). CSR interest is based totally at the theory of legitimacy which confirms that the agency maintains to paintings to make sure that the enterprise has operated according with the policies and norms winning in the society or surroundings in which

Revised Version Manuscript Received on August 14, 2019.

Mia B. Bermundo, De La Salle University, Manila, Philippines(Emai: mia.bermundo@dlsu.edu.ph)

Rodiel C. Ferrer, De La Salle University, Manila, Philippines(Emai: rodiel_ferrer@dlsu.edu.ph)

Franklin Ramirez, Student, School of Bio-Engineering, Dept. of Genetic Engineering, Philippine Accountancy and Science School College, Manila, Philippines(Emai: franklin.ramirez@dlsu.edu.ph) the organization is located, wherein the company seeks to make certain that its operational sports are common as "valid" (Deegan, 2002). On the opportunity hand, the presence of particular business enterprise governance is definitely required with the aid of an organisation. It gives higher get right of access to to capital and aids economic growth. Corporate governance additionally has broader social and institutional dimensions. One of the corporate governance policies that may have an effect on the business enterprise's operations is its preference of dividend coverage or the choice of ways a outstanding deal of the firm's earnings should be redistributed to shareholders (Baker, 2009). The firm's dividend policy is a strategic decision which determines shareholders benefits and the firm's availability of funds for continuing operations and, as a result, could be a significant mediator of the firm's value. Numerous studies have been conducted on the effect of CSR and Corporate Governance on company charge. However, there are nevertheless inconsistencies among current studies outcomes.

\section{BACKGROUND OF THE STUDY}

\section{A.Stakeholder Theory}

According to Hillman and Luce (2001), this concept emphasizes that the firm has a courting with its stakeholders and the procedures and outcomes of these relationships are of hobby. It purports that thinking about that groups reputation to enchantment to each monetary and non-financial stakeholders, they need to cognizance on assignment CSR undertakings which is probably apparently sizeable to non-monetary stakeholder agencies. This is due to the reality the company desires each of these companies to be sustainable ultimately. Freeman and Reed (1983) identified two groups of stakeholders; those who have an impact on and can be affected by the employer and people that offer assist to the firm in shape of belongings. Stakeholder idea acknowledges the long time impact that the moves of stake holders can also have at the organization. Pedersen (2004) notes that maximizing the price of 1 's stakeholder will 


\section{THE MEDIATING EFFECT OF CORPORATE SOCIAL RESPONSIBILITY AND DIVIDEND POLICY ON THE EFFECT OF CORPORATE GOVERNANCE MECHANISM ON FIRM VALUE AMONG PUBLICLY LISTED COMPANIES IN THE PHILIPPINES}

maximize the charge of the employer. Stakeholder courting will also decorate alternate. Kakabadse and Rozuel (2005) emphasizes that, for commercial enterprise perform to properly, they need to cope with a variety of materials other than its owners. Jensen (2002) proposes that the society expects the organization to perform numerous obligations in order for them to stay on. Zingales (2000) moreover suggests that agencies can best be successful by way of using preserving a tremendous courting with the society.

\section{B. Agency Theory}

Ross (1973) come to be a few of the first students to endorse the theory. It is defined as the connection a few of the proprietors and the marketers. The owners rent the agent to carry out paintings. The owners of the employer who're the principals anticipate the marketers to make selections and act in the primary's interest. From the corporation precept aspect of view, CSR is a misuse of company assets (Mc Williams and Siengel, 2005) and such resources may be utilized by corporations to interact in different worthwhile undertaking. Moral threat and corporation fee can also emerge whilst managers make selections to put money into CSR activities without any observable effect.

\section{C.Signaling Theory}

Signaling concept is useful even as two events (individuals or organizations) have access to important statistics that is the case amongst managers and shareholder or stakeholders. Typically, one birthday celebration, the sender, should pick out whether or not and the way to talk (or sign) that data (Egmond, 2015). The different birthday celebration, the receiver, should choose a way to interpret the sign.

\section{REVIEW OF RELATED LITERATURE}

The overwhelming interest in corporate governance evolved as a result of the company problem (Daily, Dalton \& Cannella, 2003). In the final 3 many years, the time period company governance emerged as a mainstream venture in boardrooms, educational conferences and policy circles round the world. According to Vo and Nguyen (2014), the primary worries of enterprise governance are associated with "the systems and techniques for the commercial organization commands and manage of corporations". Thus, they claim that it concentrates on the relationships amongst agency' controlling machine, shareholders, stakeholders and functions of board of directors. They conclude that board of administrators is seen because the maximum essential factor in corporate governance, which influences the whole enterprise and proprietors' pursuits. Agency theory and stewardship principle are two important views that provide a good sized insight into the competencies of the board in phrases of size and independence further to the features of the CEO on company price. Gupta and Fields (2009); Lin and Chang (2014); Ntim (2011); Pamburai et al., (2015) contends that a terrific correlation between proportion of outdoor directors and corporation fee at the same time as Vintilă and Gherghina (2013) and Wahba (2015) posits a terrible courting among the two. Meanwhile Burton (2000) and Wintoki et al. (2012) critiques no correlation between compositional independence and firm value.

Meanwhile, Jiraporn et al (2011) illustrated in their research that an boom inside the first-rate of corporation governance mechanisms results in better motives for corporations to boom dividends. Meaton (2004) studied corporation governance mechanisms and dividend guidelines in present day-day markets and indicated that groups with sturdy corporate governance mechanisms pay better dividends.

Over the years there may be although lots of dialogue approximately how CSR affects company value. There has never been agreement many of the empirical research. Some have located a nice correlation; others have placed a terrible one, others have located no correlation in any respect, even as others have located that it has a one in all a type impact on agencies. Flammer (2013) examined whether or no longer CSR brought about superior overall performance. The outcomes indicated a top notch dating however the have an effect on is a whole lot much less robust whilst agencies engage in better CSR levels. This encouraged for the notion that CSR has lowering high pleasant outcomes while the ranges of CSR growth. The have a have a look at of Dewi et al. (2014) determined that there has been a big direct effect among CSR and enterprise fee. In addition, primarily based on the research of Gichohi (2014), there was a advantageous however insignificant have an effect on of CSR on enterprise financial performance of companies listed in NSE. However, Johansson et al (2010) positioned a statistically insignificant courting between CSR and firm value.

\section{METHODOLOGY}

This is an explanatory research design because it sought to determine the mediation effect of CSR on the impact of corporate governance and dividend policy on firm value. Bulks of the data used quantitative in nature specifically for firm value, and dividend policy. However, for data derived from corporate governance, though quantitative in form, are based on qualitative assessment on their respective Annual Corporate Governance Report (ACGR). On the other hand, manual content analysis will be used in this study to measure the CSR practices of the sample companies. The checklist developed by Habbash (2017) based from ISO 26000 (Social Responsibility Guidance Standard) will be utilized. The checklist is composed of 17 statements on social and economic aspects of CSR. Dichotomous Scoring will be used to develop CSR Index (CSRI). Lastly, A structural equation modeling (SEM) approach will be used for the analysis.

\section{RESULTS}

\section{Descriptive Statistics}

Table 1 Suggests the records trends together with general range of observations, manner, Standard Deviation and their respective minimum and most values for the variables of Corporate governance mechanisms, CSR index, payout ratio and Tobin's Q used within the check over the duration of 12 months 2013 to yr 2016. First of all, measures of precious tendency and variation were mentioned. 
Dividend Yield ranged from $1 \%$ to $899 \%$ ( $\mathrm{M}=2.22 \%$, $\mathrm{SD}=1$.Fifty 5). Tobin's $\mathrm{Q}$ ranged from zero. 00 to five. 35 $(\mathrm{M}=1.42, \mathrm{SD}=1.15)$. Board Size ranged from 7 to 16 individuals, with a median of 10 contributors $(\mathrm{SD}=2.32)$, whilst Board Independence became beginning from zero to five individuals, with a median of three contributors $(\mathrm{SD}=0.86)$. Institutional Ownership ranged from zero\% to a hundred\%, $(\mathrm{M}=81$. Eleven\%, $\mathrm{SD}=0.27)$ while Executive Compensation ranged from $\mathrm{P} 80,000$ to $\mathrm{P} 224,514,260$, with a median of P20,403,721.87 (SD=P36,851,925.Sixty four). Besides, LOGECOM ranged from five to eight ( $\mathrm{M}=6$. Ninety four, $\mathrm{SD}=$ zero.695). In addition, CSR index range from $0 \%$ to $82.35 \%$.

\begin{tabular}{llll} 
Variables & N & Min & Max \\
\hline Dividend Yield & 188 & .01 & 8.99 \\
Tobin's Q & 188 & .00 & 5.35 \\
Board Size & 188 & 7 & 16 \\
Board Independence & 188 & 0 & 5 \\
CEO Duality & 188 & 0 & 1 \\
Executive & 188 & $80,000.00$ & $224,514,260.00$ \\
Compensation & & & \\
Institutional & 188 & .0000 & 1.0000 \\
Ownership & 188 & .0000 & .8235 \\
CSR Index & 188 & 0 & 0 \\
Valid N (listwise) & & &
\end{tabular}

\begin{tabular}{llll} 
Variables & $\mathbf{N}$ & Mean & Std. Deviation \\
\hline Dividend Yield & 188 & 2.2210 & 1.55408 \\
Tobin's Q & 188 & 1.4184 & 1.14637 \\
Board Size & 188 & 10.28 & 2.324 \\
Board Independence & 188 & 2.64 & .863 \\
CEO Duality & 188 & .54 & .500 \\
Executive & 188 & $20,403,721$ & $36,851,925$. \\
Compensation & & & \\
Institutional & 188 & .811147 & .2657770 \\
Ownership & & & .1449403 \\
CSR Index & 188 & .570713 & 0 \\
Valid N (listwise) & 188 & 0 & \\
\hline
\end{tabular}

Table 1 Descriptive Statistics

\begin{tabular}{|c|c|c|c|c|}
\hline \multirow{2}{*}{ Models } & \multirow{2}{*}{ Coef } & $\begin{array}{l}\text { Confidence } \\
\text { Intervals }\end{array}$ & & $\mathbf{P}$ \\
\hline & & $\begin{array}{ll}2.50 & 97.50 \\
\% & \%\end{array}$ & $\begin{array}{l}\text { Statis } \\
\text { ics }\end{array}$ & es \\
\hline
\end{tabular}

\section{Direct Effect $(\mathrm{N}=188)$}

$\begin{array}{llllll}\mathrm{H}_{1} \text { : } \mathrm{CSR} \rightarrow>\text { Firm Value } & -0.50 & -0.12 & 0.283 & 0.633 & 0.420\end{array}$

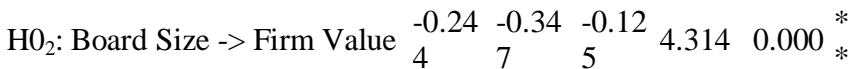

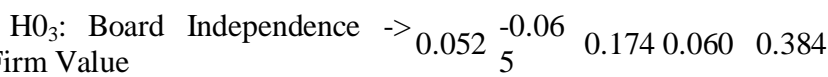

$\mathrm{HO}_{4}$ : CEO Duality $\rightarrow$ Firm-0.19 $-0.32-0.062 .9660 .003$ *

$\begin{array}{llllll}\text { Value } & 7 & 1 & 4 & 2.966 & 0.003\end{array}$

$\begin{array}{cccccc}\mathrm{H}_{5} \text { : Institutional Ownership -> } & -0.00 & -0.15 & 0.123 & 0.128 & 0.898\end{array}$

$\mathrm{HO}_{6}$ : Executive Compensation
0.104 ${\underset{2}{->}}^{-0.01} 0.2181 .7670 .047$ *

$\begin{array}{ccccccc}\mathrm{H}_{7} \text { : Dividend Policy -> Firm }-0.11 & -0.20 & -0.01 & 2.263 & 0.024 \\ \text { Value } & 4 & 8 & 1 & *\end{array}$ Value

****significant at 0.05

significance level

Mediating Effect ( $N=188)$

\begin{tabular}{|c|c|c|c|c|c|}
\hline $\mathrm{HO}_{8}: \mathrm{BS}->\mathrm{DP}->\mathrm{FV}$ & $\begin{array}{l}-0.02 \\
5\end{array}$ & $\begin{array}{l}-0.05 \\
2\end{array}$ & $\begin{array}{l}-0.00 \\
2\end{array}$ & 1.928 & 0.054 \\
\hline $\mathrm{H}_{9}: \mathrm{BI}$-> DP -> FV & 0.009 & $\begin{array}{l}-0.00 \\
6\end{array}$ & 0.033 & 30.931 & 0.352 \\
\hline $\mathrm{H}_{10}: \mathrm{CEOD}$-> DP -> FV & $\begin{array}{l}-0.01 \\
7\end{array}$ & $\begin{array}{l}-0.04 \\
3\end{array}$ & 0.000 & 1.466 & 0.143 \\
\hline $\mathrm{H}_{11}: \mathrm{IO}->\mathrm{DP}->\mathrm{FV}$ & $\begin{array}{l}-0.02 \\
7\end{array}$ & $\begin{array}{l}-0.06 \\
1\end{array}$ & $\begin{array}{l}-0.00 \\
2\end{array}$ & 1.776 & 0.076 \\
\hline $\mathrm{H}_{12}: \mathrm{EXECOM}$-> DP $->\mathrm{FV}$ & 0.005 & $\begin{array}{l}-0.01 \\
5\end{array}$ & 0.024 & 0.503 & 0.615 \\
\hline $\mathrm{H}_{13}: \mathrm{BS}->\mathrm{CSR}$-> FV & 0.113 & $\begin{array}{l}-0.03 \\
3\end{array}$ & 0.029 & 0.484 & 0.156 \\
\hline $\mathrm{HO}_{14}: \mathrm{BI}->\mathrm{CSR}$-> FV & $\begin{array}{l}-0.01 \\
6\end{array}$ & $\begin{array}{l}-0.04 \\
2\end{array}$ & 0.000 & 0.755 & 0.225 \\
\hline $\mathrm{HO}_{15}: \mathrm{CEOD}$-> CSR -> FV & 0.007 & 0.007 & $\begin{array}{l}-0.00 \\
1\end{array}$ & 1.693 & 0.059 \\
\hline $\mathrm{H}_{16}: \mathrm{IO}->\mathrm{CSR}->\mathrm{FV}$ & $\begin{array}{l}-0.04 \\
1\end{array}$ & $\begin{array}{l}-0.00 \\
2\end{array}$ & $\begin{array}{l}-0.05 \\
2\end{array}$ & 1.152 & 0.115 \\
\hline $\mathrm{H}_{17}: \mathrm{EXECOM}$-> CSR $->\mathrm{FV}$ & $\begin{array}{l}-0.02 \\
9\end{array}$ & $\begin{array}{l}-0.02 \\
3\end{array}$ & 0.046 & 61.378 & 0.096 \\
\hline \multicolumn{6}{|l|}{ Model Fit Summary } \\
\hline SRMR & 0.018 & & & & \\
\hline Chi-square & 4.934 & & & & \\
\hline NFI & 0.988 & & & & \\
\hline
\end{tabular}

*SRMR - Standardized Root Mean Square Residual; NFI - Normed Fit Index or Bentler and Bonett Index

Table 2. Structural Equation Modeling (SEM) Outcomes

\section{Direct Impact Examined}

There were seven factors tested to impact firm value. This set of factors were hypothesized under these several direct effects - (H01) CSR on FV, (H02) BS on FV, (H03) BI on $\mathrm{FV}$, (H04) CEOD on FV, (H05) EC on FV, (H06) IO on FV, and $(\mathrm{H} 07) \mathrm{DP}$ on FV. Board size $(\beta=-.244, \mathrm{p}=.000)$, Executive compensation $(\beta=0.104, p=0.047)$, Dividend Policy $(\beta=-0.114, p=0.024)$, and CEO duality $(\beta=-.197$, $\mathrm{p}=.003$ ) were significant in their impact to Firm Value. Factors including CSR $(\beta=-.508, \quad \mathrm{p}=.227), \quad$ Board independence $(\beta=.052, p=.384)$, and Institutional ownership $(\beta=-0.009, p=.898)$, were not significant in terms of their impact to Firm Value. Thus, this study rejects hypotheses $\mathrm{H} 02$, H04, H06, and H07, and fails to reject hypotheses H01, $\mathrm{H} 03$, and $\mathrm{H} 05$.

The Mediating Role of Corporate Social Responsibility on the Impact of Corporate Governance on Firm Value

The $\mathrm{p}$ values of $\mathrm{BS} \rightarrow \mathrm{CSR} \rightarrow \mathrm{FV}, \mathrm{BI} \rightarrow \mathrm{CSR} \rightarrow \mathrm{FV}$, $\mathrm{CEOD} \rightarrow \mathrm{CSR} \rightarrow \mathrm{FV}, \mathrm{IO} \rightarrow \mathrm{CSR} \rightarrow \mathrm{FV}$ and EXECOM $\rightarrow$ $\mathrm{CSR}->\mathrm{FV}$ is greater than 0.05 hence, CSR does not mediate the impact of board size, board independence, CEO duality, Institutional ownership, and Executive compensation on Firm value. Also their t-statistics are below 1.96 which are insignificant. Overall, corporate social responsibility is not proven to mediate corporate governance and firm value relationships since it has a $\mathrm{p}$ value greater than 0.05 .

The Mediating Role of Dividend Policy on the Impact of Corporate Governance on Firm Value

There was no mediation effect of dividend insurance for all of the 5 employer governance variables to company value. 


\section{THE MEDIATING EFFECT OF CORPORATE SOCIAL RESPONSIBILITY AND DIVIDEND POLICY ON THE EFFECT OF CORPORATE GOVERNANCE MECHANISM ON FIRM VALUE AMONG PUBLICLY LISTED COMPANIES IN THE PHILIPPINES}

Their p-values of extra than zero.05 indicated that there had been no mediation for those examined hypotheses. Therefore, it can be concluded that dividend insurance does now not mediate the impact of organisation governance variables on employer cost.

\section{CONCLUSION}

This study examines the effect of Corporate Governance and Corporate Social Responsibility on Firm Value. The study included all Publicly Listed Companies within the Philippines for the yr 2013-2016 except organizations in financial industry, companies with incomplete records, and companies currently under rehabilitation. Based at the consequences, it can be concluded that Corporate Social Responsibility does no longer have an effect on firm price. On the other hand, Corporate Governance mechanisms like board size, board independence, CEO duality, and Executive compensation notably influences organization charge. Furthermore, CSR and Dividend policy does not mediate the impact of company governance mechanisms on company price.

Because of this, Philippine businesses may additionally recall assessing the significance of company governance practices in figuring out corporation problems. Therefore, the significance of employer governance can not be over-emphasized since it enhances the organizational weather for the internal structures and overall performance of a company. Indeed, company governance brings to undergo thru outside impartial administrators, new measurement for effective strolling of a corporate entity thereby improving a firm's corporation entrepreneurship and competitiveness. The adoption of enterprise principles is a large step within the path of developing safeguards toward corruption and mismanagement, promoting transparency in financial life and attracting greater home and foreign places funding. In addition, an powerful software to combat corruption is also able to shielding shareholder price is an critical requirement for development of company governance practices within the Philippines. In relation to mediation evaluation, the have a look at employed dividend coverage as one of the mechanisms to reduce company fee springing up from the shareholder-agent struggle. This can offer guidance for corporations in the preference and implementation of their very very own corporate governance mechanisms. Firms should ensure that their dividend policies are supporting the needs of both large and small shareholders.

\section{REFERENCES}

1. Ararat, M. (2006). "Corporate Social Responsibility" Across Middle Easy and North Africa. Cairo: Egyptian Corporate Responsibility Center. Aras, G., Aybars

2. Arsoy, A. P., Arabici, Ö., \& Çiftcioglu, A. (2012). Corporate Social Responsibility And Financial Performance Relationship: The Case Of Turkey. The Journal of Accounting and Finance

3. Baker, H.K.(2009). Dividends and dividend policy. Hoboken,NJ:JohnWileyandSons.

4. Carningsih. 2010. Effect Of The Relationship Between Corporate Governance Financial Performance With Corporate Value (Case Study At Company Property and Real Estate Indonesia). Accounting journal. Darsono, A.
(2009). Applications Financial Statement Analysis. Yogyakarta: Liberty. Journal of Information Science and Technology, 6 (2), 49-59.

5. Carroll, A. (1999). Corporate Social Responsibility. Business and Society, 38 (3), 269

6. Campbell, J. A., W. Beranek, Stock Price Behavior on Ex-Dividend Dates, Journal of Finance, 10(4), 1955, pp. $125-429$

7. Chang, B., \& Dutta, S. (2012). Dividends and corporate governance. IUP Journal of Applied Finance, 18(4),5-30

8. Chen. H. \& Wang. X. (2011). Corporate social responsibility and corporate financial performance in China: an empirical research from Chinese firms. Corporate Governance, 11(4)

9. Choi. R (2008). Corporate social responsibility: A case study approach. Chaltenham: Edward Elgar Publishing Limited.

10. Hohnen, P. (2007). Corporate Social Responsibility: An Implementation Guide for Business. (J. Potts, Ed.) Retrieved November 2013, from International Institute for Sustainable http://www.iisd.org/pdf/2007/csr_guide.pdf.

11. Jensen, M.C., 2001, Value maximization, stakeholder theory, and the corporate objective function, European Financial Management 7, 297-317.

12. Jensen, M., 1986, "Agency Costs of Free Cash Flow, Corporate Finance, and Takeovers", American Economic Review

13. Khan, M.Y. and Jain, P.K., 1992, Financial Management: Text and Problems, Tata Mc Graw Hill Publishing Company

14. Miller, M. and Modigliani, F. (1961). Dividend Policy, Growth, and the Valuation of Shares. The Journal of Business, Vol. 34, No. 4, pp. 411-433

15. Ramirez, F. (2018). The Mediating Role of Dividend Policy on the Impact of Capital Structure and Corporate Governance Mechanisms on Firm Value among Publicly Listed Companies in the Philippines from 2013 to 2016 using Structural Equation Model. De La Salle University, Manila, Philippines.

16. Shleifer, A and R.W. Vishny, 1997, A survey of corporate governance, Journal of Finance 52, 1997, 737783.

17. Walter, J.E., 1956, "Dividend Policies and Common Stock Prices", Journal of Finance

18. W. Visser, D. Matten, M. Pohl, and N. Tolhurst, The A to $\mathrm{Z}$ of corporate social responsibility (United Kingdom: Wiley, 2010). 